Tersedia di: http://jurnal.untan.ac.id/index.php/jilo

\title{
PENGEMBANGAN ALAT LATIHAN TANGKAPAN PENCAK SILAT
}

\author{
Siti Syamsiyah ${ }^{1}$, Edi Purnomo ${ }^{2}$, Uray Gustian ${ }^{3}$ \\ ${ }^{123}$ Program Studi Pendidikan Kepelatihan Olahraga \\ Universitas Tanjungpura Pontianak \\ Email : sitisyamsiyah109@gmail.com
}

\begin{abstract}
Abstrak
Penelitian ini bertujuan mengembangkan alat latihan tangkapan pencak silat sebagai alat bantu latihan yang dapat digunakan oleh pelatih untuk melatih teknik tangkapan. Penelitian ini merupakan penelitian pengembangan yang dilakukan dengan dengan beberapa langkah, yakni: menelaah potensi dan masalah, pengumpulan data, pembuatan produk, validasi ahli, revisi produk, uji coba produk, revisi produk dan uji coba pemakaian. Validasi oleh ahli material, ahli praktisi, 15 responden sebagai uji coba tahap pertama uji produk dan 30 responden media alat bantu latihan tangkapan pencak silat. Hal ini dapat di lihat dari hasil sebagai uji coba tahap kedua uji pemakaian produk. Hasil penelitian menunjukkan bahwa "Alat Latihan Tangkapan Pencak Silat" dikategorikan Layak digunakan sebagai penilaian dari ahli material sebesar $94,28 \%$ dan ahli praktisi $80,91 \%$ serta uji coba produk skala kecil $86 \%$ dan uji coba pemakaian skala besar 96\%. Dengan demikian kesimpulan bahwa Pengembangan Alat Latihan Tangkapan Pencak Silat telah dinyatakan layak digunakan sebagai alat bantu latihan.
\end{abstract}

Kata Kunci: Latihan Tangkapan, Pencak Silat.

\begin{abstract}
This study aims to develop a training tool to catch Pencak silat as a training aid that can be used by trainers to practice catching techniques. This research is development research conducted in several steps, namely: examining potentials and problems, studying data, making products, expert validation, product revisions, product testing, product revisions, and usage trials. Validation by material experts, testing, 15 respondents as the first stage trial, and 30 respondents as the second stage trial of product usage testing. The results showed that the "Pencak Silat Catching Training Tool" was categorized as suitable for use as a tool for the training of Pencak silat capture training. This can be seen from the results of the material experts of $94.28 \%$ and health experts of $80.91 \%$ as well as small-scale product trials of $86 \%$ and large-scale use trials of $96 \%$. Thus the conclusion is that the development of the Pencak Silat Catching Training Tool has been used properly as a training aid.
\end{abstract}

Keywords: Catching training, Pencak Silat. 


\section{Jurnal Ilmu Keolahragaan Volume III Nomor 2 Oktober 2020 Siti Syamsiyah, Edi Purnomo, \& Uray Gustian \\ Tersedia di: http://jurnal.untan.ac.id/index.php/jilo}

\section{PENDAHULUAN}

Seni bela diri adalah seni untuk pertahanan diri yang dapat digunakan sebagai pengolah tubuh untuk menjaga kesehatan dan untuk penjagaan diri. Menguasai olahraga bela diri, siap secara fisik dan mental, biasanya dari bentuk serangan yang mengancam keselamatan diri (Muhammad Syahrial, 2020: 1). Pencak silat merupakan salah satu dari seni bela diri warisan dari nenek moyang sebagai budaya bangsa Indonesia yang harus dilestarikan, dibina dan dikembangkan (Erwin, 2015). Pencak silat dapat digunakan sebagai sarana untuk membangkitkan dan mengembangkan kesegaran jasmani. Pencak silat menggunakan seluruh bagian tubuh dan anggota badan secara lincah, cepat, dan tepat sasaran, disertai gerak reflek untuk mengatasi lawan (Tatang Muhtar, 2020).

Ada 4 aspek dalam ajaran Pencak silat yaitu, mental spiritual, seni, beladiri dan olahraga, masing-masing memiliki penekanan teknik yang berbeda. Sehingga memerlukan keterampilan dalam melatih agar tercapai latihan yang efektif dan efisien. Serta penting bagi seorang atlet untuk melakukan latihan. Latihan yang sering dilakukan dalam olahraga Pencak Silat yaitu dengan memberikan pengulangan gerakan berupa jurus-jurus untuk menimbulkan automatisasi gerakan. Selain itu latihan dilakukan untuk menstimulasi tubuh agar memberikan respon saat latihan, sehingga dapat mengefisiensikan dan meningkatkan performa. Latihan berjalan dengan baik apabila pelatih memiliki pengalaman serta pengetahuan mengenai program dan tujuan latihan.

Menurut Hasil Munas IPSI XIII (2013) terdapat 4 kategori pertandingan pencak silat yaitu : 1) kategori tanding, 2) kategori tunggal, 3) kategori ganda, dan 4) kategori regu. Berdasarkan uraian dari keempat kategori pertandingan pencak silat tersebut, maka yang menjadi dasar bagi seorang atlet untuk meraih prestasi yaitu penguasaan teknik dasar. Penguasaan teknik dasar menjadi landasan ataupun modal awal bagi seorang atlet beladiri pencak silat untuk menyempurnakan gerakan. Pemberian nilai tertinggi prestasi teknik dalam sebuah pertandingan yaitu pada teknik belaan lanjutan tangkapan. Menurut hasil keputusan Munas XIII (2013) suatu teknik jatuhan melalui tangkapan (tanpa melihat serangan lawan atau tidak) mempunyai nilai $1+3$, sedangkan jatuhan tanpa melalui tangkapan hanya mempunyai nilai 3 (tiga).

Terdapat 5 teknik dasar dalam pencak silat yaitu: 1) Kuda-kuda, 2) hindaran, 3) elakan, 4) tangkisan, dan 5) tangkapan. Masing - masing teknik dasar tersebut harus dikuasai oleh para pesilat agar dapat menampilkan performa yang bagus. Kudakuda yang bagus adalah kuda-kuda yang memiliki kondisi stabil dalam keadaan statis menjaga tetap kokoh. Adapun hindaran yang dimaksud adalah teknik untuk menghindar dari lawan agar tidak terkena serangan baik itu pukulan ataupun tendangan dari lawan. Hindaran ini dapat dilakukan dengan berbagai cara yaitu dengan menghindar ke arah sisi kanan atau kiri, mengangkat kaki ketika lawan memberikan tendangan atau dengan menghindar dengan cara menyilangkan kaki.

Teknik dasar elakan dalam pencak silat hamper menyerupai dengan teknik hindaran. Ketika lawan memberikan pukulan maka atlet harus melakukan elakan agar tidak terkena pukulan dari lawan. Elakan dapat dilakukan dengan berbagai cara yaitu dengan mengelak ke atas, ke bawah ataupun ke samping. Hal ini dilakukan sesuai dengan situasi dimana pukulan akan dilayangkan. Berbeda dengan teknik selanjutnya yaitu teknik tangkisan. Teknik tangkisan ini adalah teknik yang mengharuskan kita untuk kontak langsung dengan lawan. Sesuai dengan namanya, tangkisan dilakukan ketika atlet tidak dapat melakukan hindaran atuapun elakan terhadap apa yang diberikan lawan. Maka 


\section{Jurnal Ilmu Keolahragaan Volume III Nomor 2 Oktober 2020 Siti Syamsiyah, Edi Purnomo, \& Uray Gustian \\ Tersedia di: http://jurnal.untan.ac.id/index.php/jilo}

salah satu yang harus dilakukan adalah tangkisan. Tangkisan ini bisa dilakukan dengan tangan, siku maupun kaki. Bisa dilakukan dengan satu tangan ataupun dua tangan.

Teknik dasar yang terakhir adalah teknik tangkapan. Teknik ini digunakan pada saat lawan berada sangat dekat sehingga tidak mungkin melakukan hindaran, elakan maupun tangkisan. Maka teknik yang paling tepat digunakan adalah teknik tangkapan. Teknik ini bisa dilakukan dengan tangan. Untuk itu atlet harus menguasai semua teknik dasar sebelum bertanding. Latihan yang rutin dan teratur akan dapat membuat performa. Namun latihan yang monoton akan membuat atlet merasa bosan. Oleh karena itu untuk meningkatkan prestasi atlet seringkali pelatih memberikan variasi latihan teknik baik berupa pembelajaran ataupun media alat.

Berdasarkan beberapa review hasil penelitian: (Khoiroh, 2017), (Agam, Rahayu, \& Rifai, 2016), (Amrullah, 2016), (Genurianto, 2016), (Kaharuddin et al., 2017), (Nusufi, 2017), (Anam \& Hidayah, 2014), (Abdurahman, Simanjuntak, \& Purnomo, 2014), (Marlianto, Yarmani, \& Sutisyana, 2017). Menyatakan bahwa terdapat berbagai macam variasi latihan seperti latihan training xander, dan latihan plyometric depth jump modification. Aplikasi belajar teknik dasar dalam pencak silat menggunakan android, dan menggunakan sistem server kamera untuk menganalisis gerak teknik dasar tendangan sabit dan tendangan depan dalam pencak silat.

Berdasarkan uraian hasil penelitian tersebut menyatakan bahwa terdapat berbagai macam variasi latihan dan aplikasi belajar teknik dasar. Namun belum di temukannya penelitian mengenai teknik tangkapan dalam pencak silat sedangkan pada kenyataannya di dalam sebuah pertandingan gerakan yang menghasilkan poin tertinggi apabila pesilat mampu menjatuhkan lawan dengan awalan teknik belaan lanjutan yaitu teknik tangkapan. Penulis pernah melihat alat latihan tangkapan yang digunakan oleh pelatih Perguruan Terlat Sakti secara manual. Dengan penggunaan alat hanya bisa digunakan di luar ruangan dengan sistem ditancapkan ke tanah. Semakin banyak atlet yang melakukan latihan maka akan semakin besar tenaga yang harus di keluarkan oleh pelatih. Sehingga pelatih sangat memerlukan alat bantu latihan yang dapat mempermudah pelatih memberikan contoh gerakan dan dapat mengatur secara otomatis kecepatan gerak alat latihan, serta dapat digunakan di dalam maupun di luar ruangan.

Berdasarkan permasalahan tersebut salah satu upaya untuk mengembangkan alat latihan tangkapan secara manual yaitu membuat pengembangan alat latihan tangkapan secara otomatis menggunakan mesin listrik. Pengembangan alat latihan tangkapan ini menggunakan sistem kinerja yang lebih mudah dikarenakan alat akan bergerak secara otomatis sehingga pelatih hanya perlu mengawasi gerakan atlet maupun mengatur kecepatan alat.

\section{METODE}

Desain penelitian yang digunakan adalah penelitian pengembangan (Research and Development). Disain penelitian dan pengembangan adalah suatu proses atau langkah-langkah untuk mengembangkan suatu produk baru atau menyempurnakan produk yang telah ada, yang dapat di pertanggungjawabkan (Nana, 2015). Sedangkan Menurut (Sugiyono, 2016) Metode penelitian dan pengembangan adalah metode penelitian yang digunakan untuk meneliti dalam upaya mengembangkan produk yang telah ada (inovasi) maupun untuk menciptakan produk baru (kreasi) yang teruji. Melalui metode pengembangan akan menghasilkan produk yang efektif dan efisien sehingga dapat diaplikasikan dengan baik dan bermanfaat bagi penggunanya. Selain itu, produk hasil pengembangan dapat 


\section{Jurnal Ilmu Keolahragaan Volume III Nomor 2 Oktober 2020 Siti Syamsiyah, Edi Purnomo, \& Uray Gustian \\ Tersedia di: http://jurnal.untan.ac.id/index.php/jilo}

memberikan solusi dan mengatasi permasalahan.

Penelitian ini bertujuan untuk menghasilkan produk alat bantu latihan untuk teknik tangkapan pencak silat. Alat tersebut terinspirasi dari media youtube alat latihan dasar tangkapan pencak silat secara manual oleh Perguruan Terlat Sakti Bengkulu.

Tahapan pengembangan dalam penelitian ini menggunakan metode research and development (R \& D) dari Sugiyono (2016) sebagai berikut: 1) Telaah potensi dan masalah, 2) Konfirmasi ke lapangan, 3) Mendisain produk, 4) PEmbuatan rangka, 5) Validasi produk, 6) Revisi produk, 7) Uji Coba produk, 8) revisi produk tahap 2, 9) Uji coba pemakaian. Langkah pertama adalah mengindentifikasi dan menelaah potensi dan masalah. Pada penelitian ini alat latihan dasar tangkapan merupakan alat latihan yang pertama kali peneliti lihat pada media youtube oleh Perguruan Terlat sakti. Namun sistem kerja alat tersebut masih secara manual dilakukan oleh seorang pelatih untuk mengatur kecepatan dengan cara mendorong tongkat ke depan atlet. langkah selanjutnya adalah pengumpulan data. Berdasarkan telaah mengenai potensi masalah diatas langkah berikutnya adalah mengkornfirmasi keadaan di lapangan. Informasi tersebut akan memaparkan alat-alat yang digunakan saat latihan teknik tangkapan. Langkah ketiga adalah mendesain produk. Peneliti merancang dan mendesain rencana produk yang sesuai dengan hasil telaah potensi dan masalah dan konfirmasi yang ada di lapangan. Produk dalam penelitian ini adalah terciptanya sebuah alat latihan tangkapan pencak silat berdasarkan pengembangan dari alat latihan tangkapan yang sudah ada. Tahap berikutnya dalam penelitian ini adalah pembuatan rangka ataupun miniature alat latihan tangkapan pencak silat.

Validasi Produk merupakan langkah berikutnya dalam penelitian ini. Dalam rangka menghasilkan alat yang tepat dan bermanfaat maka validasi produk snagat diperlukan untuk menilai rancangan produk. Validasi produk dilakukan dengan cara menghadirkan beberapa judge yang berpengalaman untuk menilai produk baru yang dirancang. Setiap judge akan menilai desain produk, sehingga dapat diketahui kelemahan dan kekuatannya. Namun pada tahap ini, peneliti tidak memvalidasi desain tapi langsung validasi produk. Produk dibuat sesudah tahap desain produk. Judge material memberi penilaian tentang penggunaan material pada produk pengembangan alat latihan tangkapan pencak silat. Adapun hal yang dinilai,yaitu : aspek fisik, keamanan, dan keefektifan. Judge pelaku atau paktisi memberikan penilaian penggunaan alat latihan tangkapan pencak silat. Dengan kriteria penilaian yaitu : keamanan dan keefektifan.

Langkah berikutnya adalah revisi produk. Setelah validasi produk oleh para judge, diketahui kelemahan dari produk tersebut. Kelemahan produk tersebut selanjutnya diperbaiki berdasarkan masukan dari judge agar menjadi lebih baik lagi. Langkah berikutnya adalah tahap uji coba, tahap ini dilakukan setelah validasi oleh judge selesai dan dinyatakan layak untuk diuji cobakan di lapangan. Uji coba produk dilakukan pada kelompok Mahasiswa kecaboran Pencak Silat Pendidikan Kepelatihan Olahraga.

Langkah keenam adalah revisi produk. Setelah diperoleh data uji coba produk dalam skala kecil. Revisi tahap II merupakan tahap terakhir revisi dan tidak ada lagi revisi sesudah uji coba pemakaian. Kemudian dilakukan Uji Coba Pemakaian, merupakan langkah untuk mendapatkan data dalam skala besar. Penelitian dilakukan pada responden atau atlet pencak silat perguruan Tapak Suci. Dalam tahap ini alat sudah melewati uji coba produk serta revisi produk. Alat yang sudah diperbaiki siap untuk di uji coba kembali oleh atlet Pencak Silat, dengan menilai kekurangan atau hambatan yang ada untuk perbaikan selanjutnya. 


\section{Jurnal Ilmu Keolahragaan Volume III Nomor 2 Oktober 2020 \\ Siti Syamsiyah, Edi Purnomo, \& Uray Gustian \\ Tersedia di: http://jurnal.untan.ac.id/index.php/jilo}

Teknik pengumpulan data menggunakan angket kepada responden. Adapun instrument yang digunakan pada penelitian pengembangan ini menggunakan Skala Likert. Angket yang digunakan dalam penelitian ini adalah angket tertutup dan terbuka, dan disertai kolom saran. Angket diberikan kepada judge material, judge praktisi dan uji coba produk skala kecil pada mahasiswa pendidikan kepelatihan olahraga kecaboran pencak silat dan uji coba pemakaian pada atlet pencak silat.

Data yang terkumpul kemudian dianalisis untuk mengetahui kualitas produk pengembangan yang dihasilkan. Pengumpulan data yang dihasilkan dari validasi produk, uji coba produk dan uji coba pemakaian. Adapun validasi produk akan menggunakan rumus kelayakan untuk menganalisis hasil data dari ahli (Sugiyono, 2013). Uji coba tahap I mengenai produk dan Uji coba pemakaian menggunakan kriteria kelayakan, sehingga peneliti dapat menyimpulkan hasil kelayakan alat sesuai dengan kriteria.

\section{HASIL}

\section{Hasil penilaian Judge}

Ahli material dalam penelitian ini menggunakan judge yang mumpuni dalam bidang teknik. Adapun hasil validasi dari judge material dapat dilihat pada table 1 .
Penilaian oleh judge material mengenai produk "Pengembangan Alat Latihan Tangkapan Pencak Silat" menunjukkkan bahwa untuk penilaian tentang aspek fisik sebesar 100\% yang di kategorikan "Sangat Layak", untuk aspek keamanan sebesar 90\% yang di kategorikan "Sangat Layak", dan untuk aspek keefektifan sebesar 90\% yang di kategorikan "Sangat Layak". Total penilaian uji kelayakan penelitian "Pengembangan Alat Latihan Tangkapan Pencak Silat" menurut ahli material sebesar 94,28 \% dikategorikan "Sangat Layak" untuk diuji cobakan ke tahap berikutnya.

Judge praktisi dilakukan oleh Bapak Azwar seorang pelatih Pencak Silat Kota Pontianak. Beliau memiliki pengalaman dalam melatih atlet dari beberapa perguruan. Hasil penilaian oleh ahli praktisi mengenai produk "Pengembangan Alat LatihanTangkapan Pencak Silat" menunjukkkan bahwa untuk penilaian tentang aspek keamanan sebesar 93,33\% yang di kategorikan "Sangat Layak", dan untuk aspek keefektifan sebesar 78,94\% yang di kategorikan "Layak". Skor penilaian uji kelayakan penelitian "Pengembangan Alat Latihan Tangkapan Pencak Silat" menurut ahli praktisi sebesar 80,91\% dikategorikan "Layak" untuk diuji cobakan ke tahap berikutnya.

Tabel 1. Hasil Validasi Oleh Judge Material

\begin{tabular}{|c|c|c|c|c|c|}
\hline No. & $\begin{array}{c}\text { Faktor yang } \\
\text { dinilai }\end{array}$ & $\begin{array}{l}\text { Nilai yang } \\
\text { diperoleh }\end{array}$ & $\begin{array}{c}\text { Nilai } \\
\text { maksimal }\end{array}$ & Prosentase & Kriteria \\
\hline 1. & Fisik & 30 & 30 & $100 \%$ & Sangat layak \\
\hline 2. & Keamanan & 18 & 20 & $90 \%$ & Sangat layak \\
\hline 3. & Keefektifan & 18 & 20 & $90 \%$ & Sangat layak \\
\hline & Skor Total & 66 & 70 & $94,28 \%$ & Sangat layak \\
\hline \multicolumn{6}{|c|}{ Tabel 2. Hasil Validasi Oleh Ahli Praktisi } \\
\hline No. & $\begin{array}{c}\text { Faktor yang } \\
\text { dinilai }\end{array}$ & $\begin{array}{l}\text { Nilai yang } \\
\text { diperoleh }\end{array}$ & $\begin{array}{c}\text { Nilai } \\
\text { maksimal }\end{array}$ & Prosentase & Kriteria \\
\hline 1. & Keamanan & 14 & 15 & $93,33 \%$ & Sangat layak \\
\hline 2. & Keefektifan & 75 & 95 & $78,94 \%$ & layak \\
\hline & kor Total & 89 & 110 & $80,91 \%$ & layak \\
\hline
\end{tabular}




\section{Jurnal Ilmu Keolahragaan Volume III Nomor 2 Oktober 2020 \\ Siti Syamsiyah, Edi Purnomo, \& Uray Gustian \\ Tersedia di: http://jurnal.untan.ac.id/index.php/jilo}

\section{Hasil Penilaian Responden Uji Coba Produk}

Berdasarkan hasil penilaian produk "Pengembangan Alat Latihan Tangkapan Pencak Silat" oleh 15 Responden, di analisis menggunakan kriteria interpretasi skor. Hasil perhitungan uji coba produk "Pengembangan Alat latihan Tangkapan Pencak Silat" menunjukkan bahwa untuk aspek keamanan sebesar 86,13\% dikategorikan "Sangat Layak", untuk aspek kenyamanan sebesar 85,07\% dikategorikan "Sangat Layak", dan untuk aspek kemudahan sebesar $86,67 \%$ dikategorikan "Sangat Layak". Total perhitungan uji kelayakan penelitian "Pengembangan Alat Latihan Tangkapan Pencak Silat" menurut responden sebesar $86 \%$ dikategorikan "Sangat Layak" untuk diuji cobakan ke tahap berikutnya.

Tabel 3. Data Hasil Penilaian Responden Uji Coba Produk

\begin{tabular}{clcccc}
\hline No. & $\begin{array}{c}\text { Faktor yang } \\
\text { dinilai }\end{array}$ & $\begin{array}{c}\text { Nilai yang } \\
\text { diperoleh }\end{array}$ & $\begin{array}{c}\text { Nilai } \\
\text { maksimal }\end{array}$ & Prosentase & Kriteria \\
\hline 1. & Keamanan & 323 & 375 & $86,13 \%$ & Sangat layak \\
\hline 2. & Kenyamanan & 319 & 375 & $85,07 \%$ & Sangat layak \\
\hline 3. & Kemudahan & 390 & 450 & $86,67 \%$ & Sangat layak \\
\hline & Skor Total & 1032 & 1200 & $86 \%$ & Sangat layak \\
\hline
\end{tabular}

\section{Hasil Penilaian Responden Uji Coba Pemakaian}

Berdasarkan hasil penilaian produk "Pengembangan Alat Latihan Tangkapan Pencak Silat" oleh 30 Responden, di analisis menggunakan kriteria interpretasi skor. Hasil perhitungan uji coba pemakaian "Pengembangan Alat latihan Tangkapan Pencak Silat" menunjukkan bahwa untuk aspek keamanan sebesar 96,8\% dikategorikan "Sangat Layak", untuk aspek kenyamanan sebesar 95,6\% dikategorikan "Sangat Layak", dan untuk aspek kemudahan sebesar 95,67\% dikategorikan "Sangat Layak". Total perhitungan uji kelayakan penelitian "Pengembangan Alat Latihan Tangkapan Pencak Silat" menurut responden sebesar $96 \%$ dikategorikan "Sangat Layak" yang dapat diartikan bahwa produk tersebut "Sangat Layak" untuk digunakan sebagai alat bantu latihan.

Tabel 4. Hasil Penilaian Responden Uji Coba Pemakaian

\begin{tabular}{clcccc}
\hline No. & $\begin{array}{c}\text { Aspek yang } \\
\text { dinilai }\end{array}$ & $\begin{array}{c}\text { Skor yang } \\
\text { diperoleh }\end{array}$ & $\begin{array}{c}\text { Skor } \\
\text { maksimal }\end{array}$ & Presentase & Kategori \\
\hline 1. & Keamanan & 726 & 750 & $96,8 \%$ & Sangat layak \\
\hline 2. & Kenyamanan & 717 & 750 & $95,6 \%$ & Sangat layak \\
\hline 3. & Kemudahan & 861 & 900 & $95,67 \%$ & Sangat layak \\
\hline & Skor Total & 2304 & 2400 & $96 \%$ & Sangat layak \\
\hline
\end{tabular}

Berdasarkan hasil penilaian dari judge material, judge praktisi, dan para responden uji coba produk serta uji coba pemakaian pada penelitian "Pengembangan Alat Latihan Tangkapan Pencak Silat" menyatakan bahwa kualitas media alat bantu latihan tangkapan pencak silat dikategorikan "Layak" untuk digunakan.

Beberapa gerak dasar yang sudah diuraikan tersebut maka, atlet dapat melakukan gerak belaan lanjutan yaitu teknik tangkapan dengan cara menangkap lengan atau tungkai dari serangan lawan seperti gerak menahan pada alat bantu latihan. Teknik tangkapan yang dapat dilakukan atlet yaitu: (1) teknik tangkapan dari dalam ke luar dengan menggunakan tangan diawali dengan melakukan hindaran atau elakan. (2) Tangkapan dari dalam ke luar maupun dari luar ke dalam 


\section{Jurnal Ilmu Keolahragaan Volume III Nomor 2 Oktober 2020 Siti Syamsiyah, Edi Purnomo, \& Uray Gustian \\ Tersedia di: http://jurnal.untan.ac.id/index.php/jilo}

menggunakan lengan dengan diawali hindaran atau elakan. (3) Tangkapan menggunakan dua tangan rapat searah menggunakan kedua tangan mengikuti arah serangan atau alat.

\section{PEMBAHASAN}

Pada awal pengembangan alat latihan tangkapan pencak silat ini didesain dan diproduksi menjadi sebuah produk awal berupa alat bantu latihan tangkapan pencak silat untuk atlet pemula maupun atlet senior. Proses pengembangan melalui prosedur penelitian dan pengembangan. Kemudian produk di kembangankan dengan bantuan seseorang yang menguasai teknik industri, setelah produk awal dihasilkan maka perlu dievaluasi oleh ahli material dan ahli praktisi. Tahap penelitian selanjutnya dilakukan dengan uji coba produk dalam skala kecil dan uji coba pemakaian dalam skala besar.

Produk dalam tahap I sudah melewati tahap pembuatan dan siap untuk di validasi oleh ahli material dan ahli praktisi. Kemudian produk dalam tahap II menghasilkan data penilaian ahli material dan ahli praktisi dengan disertai saran dari ahli material bahwa pengatur kecepatan dimmer AC $220 \mathrm{~V}$ dihilangkan, diganti langsung dengan penggunaan pulley dengan rasio diameter yang berbeda, hanya saja kecepatan alat tangkapan pencak silat menjadi konstan (tidak bisa diatur sesuai keinginan) namun pada produk tahap II peneliti tidak menghilangkan dimmer AC $220 \mathrm{~V}$ yang sudah di sepakati dengan ahli material dikarenakan menghilangkan dimmer AC 220 $\mathrm{V}$ perlu adanya biaya tambahan untuk mengganti menggunakan pulley dengan rasio diameter yang berbeda yang harus dicocokkan terlebih dahulu dengan mesin motor listrik serta harus menentukan kecepatan konstan alat sedangkan untuk atlet pemula dan senior kecepatan alat yang digunakan berbeda. Ahli praktisi memberikan saran untuk memperpanjang rotan, pada produk tahap II rotan sudah diganti dengan panjang $165 \mathrm{~cm}$ disertai dengan balutan busa pada tiap-tiap ujung tongkat agar lebih aman saat digunakan oleh atlet. Hasil penilaian dapat dijabarkan dalam pembahasan berikut.

\section{Pengujian kepada ahli material}

Hasil uji angket kepada ahli material menunjukkan tingkat kelayakan sebesar 94,28\% yang berarti penelitian Pengembangan Alat Latihan Tangkapan Pencak Silat "Sangat Layak" digunakan dalam alat bantu latihan ke depan.

\section{Pengujian kepada ahli praktisi}

Hasil uji angket kepada ahli praktisi menunjukkan tingkat kelayakan sebesar $80,91 \%$ yang berarti penelitian Pengembangan Alat Latihan Tangkapan Pencak Silat "Layak" digunakan dalam alat bantu latihan ke depan.

\section{Uji coba produk dalam skala kecil}

Hasil uji responden mengenai penelitian "Pengembangan Alat Latihan Tangkapan Pencak Silat" menunjukkan bahwa untuk penilaian tentang aspek keamanan sebesar 86,13\% dikategorikan "Sangat Layak", untuk aspek kenyamanan sebesar 85,07\% dikategorikan "Sangat Layak", dan untuk aspek kemudahan sebesar 86,67\% dikategorikan "Sangat Layak". Total perhitungan uji kelayakan penelitian "Pengembangan Alat Latihan Tangkapan Pencak Silat" menurut responden sebesar $86 \%$ dikategorikan "Sangat Layak" untuk diuji cobakan ke tahap berikutnya.

\section{Uji coba pemakaian dalam skala besar}

Hasil uji responden mengenai penelitian "Pengembangan Alat Latihan Tangkapan Pencak Silat" menunjukkan bahwa untuk penilaian tentang aspek keamanan sebesar 96,8\% dikategorikan "Sangat Layak", untuk aspek kenyamanan sebesar 95,6\% dikategorikan "Sangat Layak", dan untuk aspek kemudahan sebesar 95,67\% dikategorikan "Sangat Layak". Total perhitungan uji kelayakan penelitian "Pengembangan Alat Latihan Tangkapan Pencak Silat" menurut responden sebesar 96\% dikategorikan "Sangat Layak" yang dapat diartikan bahwa produk tersebut "Sangat Layak" untuk digunakan sebagai alat bantu latihan. 


\section{Jurnal Ilmu Keolahragaan Volume III Nomor 2 Oktober 2020 Siti Syamsiyah, Edi Purnomo, \& Uray Gustian \\ Tersedia di: http://jurnal.untan.ac.id/index.php/jilo}

\section{Keterbatasan penelitian}

Penelitian Pengembangan Alat Latihan Tangkapan Pencak Silat mempunyai beberapa keterbatasan dalam penelitian. Sampel uji coba pemakaian produk masih terbatas, dikarenakan keterbatasan waktu atlet atau responden. Di tengah maraknya wabah virus covid-19 peneliti mengalami kendala dalam pengambilan data dikarenakan tempat latihan di tutup sementara dan pelatih meliburkan kegiatan para atlet untuk latihan di perguruan, namun atlet tetap latihan di rumah masing - masing. Pembuatan alat yang membutuhkan waktu lama sehingga menghambat proses penelitian, dikarenakan pembuat alat adalah seorang mahasiswa tahap akhir yang sedang dalam penyusunan skripsi.

\section{KESIMPULAN}

Hasil dari penelitian R\&D yang dilakukan pada "Pengembangan Alat Latihan Tangkapan Pencak Silat" dikategorikan Layak digunakan sebagai media alat bantu latihan tangkapan pencak silat. Hal ini dapat terlihat dari hasil penilaian dari judge material sebesar 94,28\% dan judge praktisi $80,91 \%$ serta uji coba produk tahap pertama $86 \%$ dan uji coba pemakaian sebesar $96 \%$.

\section{SARAN}

Penelitian R\&D alat latihan tangkapan telah dinyatakan valid oleh judge material dan judge praktisi, maka peneliti menyampaikan beberapa saran sebagai berikut.

1. Bagi praktisi olahraga khususnya atlet dan pelatih agar dapat menggunakan dan memanfaatkan alat latihan tangkapan sebagai alat bantu dalam proses latihan pencak silat untuk dapat meningkatkan kemampuan dan keterampilan atlet dalam melakukan teknik dasar tangkapan.

2. Bagi praktisi pengembangan alat dapat menguji tingkat keefektifannya dalam latihan dengan melakukan penelitianpenelitian terhadap pengembangan alat latihan tangkapan pencak silat dan membuat alat latihan ataupun alat-alat olahraga kepelatihan yang lebih bervariasi.

3. Bagi mahasiswa pendidikan kepelatihan olahraga kecabangan pencak silat diharapkan dapat mengembangkan penelitian pengembangan yang sejenis seperti alat latihan tangkapan pencak silat menjadi lebih menarik dan efektif.

\section{DAFTAR PUSTAKA}

Abdurahman, R. M., Simanjuntak, V., \& Purnomo, E. (2014). Keterampilan Gerak Dasar Tendangan Sabit di Perguruan Pencak Silat Kijang Berantai Kota Pontianak. Jurnal Pendidikan Dan Pembelajaran, 3(6).

Agam, G. A., Rahayu, S., \& Rifai, A. (2016). Pengaruh Gaya Mengajar Guided Discovery dan Tingkat Motor Educability terhadap Hasil Belajar Pencak Silat. Journal of Physical Education and Sports, 5(2), 134-139. Amrullah, R. (2016). Pengaruh Latihan Training Resistense Xander Terhadap Kemampuan Tendangan Sabit Pencak Silat. Jurnal Pendidikan Olahraga, 4(1), 88-100.

Anam, A. K., \& Hidayah, T. (2014). Analisis Gerak Tendangan Depan pada Ekstrakurikuler Pencak Silat. Journal of Sport Sciences and Fitness, 3(3).

Erwin Setyo Kriswanto. (2015). Pencak silat. Yogyakarta : Pustaka Baru.

Genurianto, G. (2016). Meningkatkan power otot tungkai melalui latihan plyometric depth jump modification pada pesilat remaja putra perguruan silat persinas asad sleman. Pendidikan Jasmani Kesehatan Dan Rekreasi, 5(6).

Hasil keputusan munas XIII. (2013). Peraturan Pertandingan Pencak Silat. Jakarta: Pengurus besar ikatan pencak silat Indonesia.

Johansyah Lubis. (2014). Pencak silat edisi kedua. Jakarta : Raja grafindo Persada. 
Tersedia di: http://jurnal.untan.ac.id/index.php/jilo

Kaharuddin, M. Z., Razak, S. B. K., Kushairi, M. I., Rahman, M. S. A., An, W. C., Ngali, Z., ... Yusup, E. M. (2017). Biomechanics Analysis of Combat Sport (Silat) By Using Motion Capture System. In IOP Conference Series: Materials Science and Engineering (Vol. 165, p. 12028). IOP Publishing.

Khoiroh, U. U. (2017). Aplikasi Belajar Teknik Dasar Pencak Silat (PSH) untuk Pemula Menggunakan Android. Jurnal Mahasiswa Fakultas Teknik, $1(1), 8$.

Marlianto, F., Yarmani, Y., \& Sutisyana, A. (2017). Analisis Tendangan Sabit pada Perguruan Pencak Silat Tapak Suci di Kota Bengkulu. Kinestetik, $1(2)$.
Muhammad Syahrial. (2020). Buku Jago Bela Diri. Tanggerang Selatan : Cemerlang.

Nana Syaodih Sukmadinata. (2017). Metode Penelitian Pendidikan. Bandung: Remaja Rosdakarya.

Nusufi, M. (2017). Hubungan Kelentukan Dengan Kemampuan Kecepatan Tendangan Sabit Pada Atlet Pencak Silat Binaan Dispora Aceh (Pplp Dan Diklat) Tahun 2015. Jurnal Ilmu Keolahragaan, 14(1), 35-46.

Sucipto. (2007). Modul Pembelajaran Pencak Silat. Bandung: FPOK UPI.

Sugiyono. (2016). Metode Penelitian Kuantitatif, Kualitatif Dan $R \& D$. Bandung: Afabeta.

Tatang Muhtar. (2020). Pencak Silat. Jawa Barat: UPI Sumedang. 